JERZY MRÓZ

DARIUSZ FELKA

ADAM BROJA

MARCIN MAEACHOWSKI

\title{
Devices for measuring ventilation parameters and methane concentration as well as concept of complex monitoring of methane hazard in longwall area
}

\begin{abstract}
This paper discusses the issue of the methane hazard occurring in the longwall areas of hard coal deep mines along with ways of overcoming this hazard. The authors describe devices for measuring the parameters of the underground environment in the exploitation area. Then, they present the results of tests to determine the methane hazard level in the longwall area. The parameters of ventilation-, absolute-, and criteria-methane-bearing capacity are determined based on online measurements of ventilation and gas parameters. The presented results are the effects of the European project AVENTO (Advanced tools for monitoring ventilation and methane emission).
\end{abstract}

Key words: monitoring systems, measuring equipment, methane hazard, mine ventilation, coal mines

\section{INTRODUCTION}

The basic sources of methane emission in mines are longwalls and excavation headings [1]. In order to determine the volume of the methane emitted, various methods have been developed. In the phase of design and exploitation, Polish mines use a method by the GIG Central Mining Institute - Experimental Coal Mine Barbara [2]. The method describes the rules for determining the acceptable content of methane in the excavations of exploited areas.

The online assessment is carried out on the basis of measurements made by methane-concentration monitoring systems and the signaled exceeded threshold (acceptable) values. The assessment depends on the knowledge and activities of the supervisor and does not take into account the impact of important source factors resulting from coal exploitation, ventilation, nor methane drainage. Thus, the supervisor's decisions and automatic shutdowns of energy take place after the hazard actually occurs. All deeper analyses of methane hazard are conducted by ventilation experts with relatively long delays resulting from the applied method of collecting data indispensable for the assessment. During the analysis, the impact of the following factors on methane hazard is discussed: coal breaking, methane streams in ventilation air and methane drainage pipelines, and changes of ventilation parameters (distribution of pressure and air flow in the area). Such analyses are carried out in 24-hour and weekly cycles.

The article features the results of research conducted in the Institute of Innovative Technologies EMAG. The objectives of the research were the following:

- better use of measurement data from the monitoring system in the calculations of ventilation parameters and gas disturbances when measured changes occur, - checking the possibility of the complex online assessment of ventilation condition and methane hazard in the longwall area on the basis of the calculated criteria as well as the ventilationmethane-bearing and methane-drainage-bearing capacities. 


\section{CHARACTERISTICS OF MEASURING EQUIPMENT}

The systems for monitoring ventilation hazards in hard coal mines carry out measurements in three basic domains [3, 4]:

- methane hazard,

- fire hazard,

- selected parameters of the ventilation network.

The underground environment in the exploitation area is monitored by sensors that measure the following parameters: methane concentration, carbon oxide concentration, oxygen concentration, air flow velocity, temperature, barometric pressure, and other gases not required by regulations. These sensors work in different systems employed in the given mine (e.g., SMP, CST [12]).

The measurement system is composed of the following sensors:

- methane meters of different types that are independent underground measuring devices and connected directly to output circuits of the surface operating center,

- carbon oxide sensors,

- methane meters to be connected with the underground operating center,

- stationary oxygen meters,

- sensors for measuring air temperature and humidity,

- ultrasound stationary anemometers,

- differential pressure sensors for air stoppings and main fans.

In addition, the tests made use of mobile sensors for measuring the following ventilation air parameters:

- methane concentration,

- airflow velocity,

- absolute pressure.

It is particularly important to monitor the longwall areas, where the changes in excavations and rock mass are the fastest. Stationary measurements of methane in the working excavation, measurements of fire hazard, absolute pressure, temperature, humidity, and differential pressure will allow us to monitor online the measured quantities, calculate derivative parameters (such as methane bearing capacity), and react quickly to the hazard.

\subsection{Sensors and devices for measuring ventilation parameters and methane concentration used in coal mines}

Below, we present devices for measuring the ventilation parameters that are most-frequently used in Polish mines $[12,13]$. We did not take into account devices for fire detection and air-quality measuring devices, such as oxygen meters, carbon oxide sensors, carbon dioxide sensors, or other gases (excluding methane measuring sensors).

1. Sensors for measuring air temperature and humidity: - Humidity measurement:

- CW-1 humidity sensor, made by EMAG, powered from an underground station, humidity measurement rescaled to a voltage output of $0.4-2.0 \mathrm{~V}$.

- Temperature measurement:

- CTG-2 rock mass temperature sensor, made by EMAG, powered from an underground station, temperature measurement rescaled to a voltage output of $0.4-2.0 \mathrm{~V}$.

- Humidity and temperature measurement:

- DHT sensor for measuring humidity, temperature, and pressure with digital data transmission, made by EMAG-SERWIS,

- CSHT-1 humidity and temperature sensor, made by Haso, co-operating mainly with a CST-40(A) telemetric switchboard in the range of data transmission,

- CSHT-2 humidity and temperature sensor, made by Haso, co-operating with a CST-40(A) telemetric switchboard through an analogue CSA-1 switchboard,

- SC-PS system sensors for the online measurement of temperature, air humidity, and absolute pressure, made by Carboautomatyka. These can work in three transmission standards: with a digital FSK signal, a voltage signal of $0.4-2 \mathrm{~V}$ or $1-5 \mathrm{~V}$, and a frequency coded signal of $5-12 \mathrm{kHz}$,

- TH intrinsically safe temperature and humidity sensor, made by Sevitel, with digital transmission through a KTM-1 converter,

- MIC6410x relative humidity sensor with temperature measurement, made by Micon.

2. Stationary anemometers:

- TX5922 stationary anemometer - an ultrasound sensor for measuring airflow velocity, made by Trolex; it works on the principle of a vortex in a range of $0.5-30 \mathrm{~m} / \mathrm{s}$; distributed in Poland by Micon,

- AS-2 (AS-3) stationary anemometer, made by EMAG, powered from an underground station; it measures air velocity in a range of $0-15 \mathrm{~m} / \mathrm{s}$; rescaled to a voltage output of $0.4-2.0 \mathrm{~V}$ or current signal of 4-20 mA, 
- AS-3ES anemometer for the online measurement of airflow velocity, powered by direct voltage of an intrinsically safe power supply device; it generates an output signal in the voltage standard; made by EMAG-SERWIS,

- AS-4ES anemometer for the online measurement of airflow velocity, powered from a surface station by means of a telephone line along which data transmission is conducted, made by EMAG-SERWIS,

- CSV-5 stationary anemometer for measuring air velocity and determining airflow direction by means of a thermal converter; it also measures air temperature and humidity; made by Haso,

- SAS-5 (SAT-1) stationary vane anemometer for the online measurement of airflow velocity, made by the Strata Mechanics Research Institute of the Polish Academy of Sciences, frequency or voltage transmission in co-operation with an underground station,

- MPP stationary vane anemometer for the online measurement of airflow velocity, made by the Strata Mechanics Research Institute of the Polish Academy of Sciences, distributed by Carboautomatyka; it also measures ambient temperature.

3. Sensors for measuring underground atmospheric pressure:

- BM-2 stationary intrinsically safe microprocessor barometer, made by EMAG, designed to co-operate with a surface central station, equipped with a backup battery,

- THP-1 stationary sensor of air physical parameters, made by EMAG, designed to cooperate with a surface central station, equipped with a backup battery,

- THP-2 stationary sensor of air physical parameters, made by EMAG-SERWIS on EMAG's license; it conducts precise measurements of absolute pressure, air temperature, and humidity,

- DPT sensor, made by EMAG-SERWIS, for the online monitoring of air relative humidity, temperature, and pressure, powered from a surface station by means of a telephone line,

- CSPA-2 sensor for measuring atmospheric pressure, humidity, and temperature, made by Haso, designed to measure absolute pressure, relative humidity, and temperature; it can cooperate with a CST-40(A) telemetric central switchboard through a CSA-1 or CSA-2 analogue switchboard; the sensor is powered by a $12 \mathrm{~V}$ intrinsically safe source.
4. Sensors for measuring differential pressure:

- CRC-4 (CRC-5, CRC-6) differential pressure sensor, made by EMAG, powered from an underground station, differential pressure measurement is rescaled to a voltage output of $0.4-2.0 \mathrm{~V}$ or adapted to frequency transmission,

- Differential pressure meter MRC0250 to MRC7500, made by EMAG, powered from an underground station; differential pressure measurement is rescaled to a voltage output of $0.4-2.0 \mathrm{~V}$,

- DRC differential pressure sensor, made by EMAG-SERWIS, designed for the online monitoring of differential pressure in mines, powered from a surface station by means of a telephone line,

- MIC1303 bi-stable differential pressure sensor, made by Micon, designed to monitor differential pressure between two measurement points,

- SC-RC system sensors for the online measurement of differential pressure, made by Carboautomatyka; they can work in three transmission standards: with a digital signal FSK, a voltage signal of $0.4-2 \mathrm{~V}$ or $1-5 \mathrm{~V}$, and a frequency coded signal of $5-12 \mathrm{kHz}$.

5. Stationary methane meters for online measurements:

- Sensor of CMM-1 microprocessor methane meter, made by EMAG,

- MM-1/V1 (MM-2) microprocessor methane meter, made by EMAG,

- Sensor of CMW-1 high-concentration methane meter, made by EMAG,

- TX3261, TX6321, and MIC6321 methane meters, made by Micon,

- IMS-1 intrinsically safe stationary methane meter, made by Sevitel,

- CSM-1 methane meter, version R, for measuring methane content in methane drainage pipelines in hard coal mines, made by Haso,

- CSM-3i (CSM-3m) infrared sensor of methane concentration, made by Haso,

- CSM-1 (CSM-3) pellistor methane concentration sensor, made by Haso,

- SC-CH4/n, SC-CH4/s, and SC-CH4/IR system sensors for the online measurement of methane concentration in the air, made by Carboautomatyka,

- SC-CH4/W + CWx-3 system sensor for the online measurement of methane concentration in methane drainage pipelines, made by Carboautomatyka. 
6. Manual methane meters:

- MPS-1R mobile signaling gas concentration sensor, made by Haso,

- PMM-1 mobile methane meter, made by Sevitel.

The authors realize that they were not able to list all of the devices available on the market. The devices listed above for measuring ventilation parameters and methane concentration are most often used in the Polish hard coal mining industry.

\section{TESTS IN THE LONGWALL AREAS}

\subsection{Measuring devices used for tests in the mine}

\subsubsection{MM-4 methane meter}

The measurement of methane concentration was conducted by a standard device adapted in the majority of Polish hard coal mines. The MM-4 device (Fig. 1) has good metrological characteristics and a short response time. MM-4 makes use of the standard and most-common principle of methane concentration measurement based on thermal-catalytic converters called pellistors.

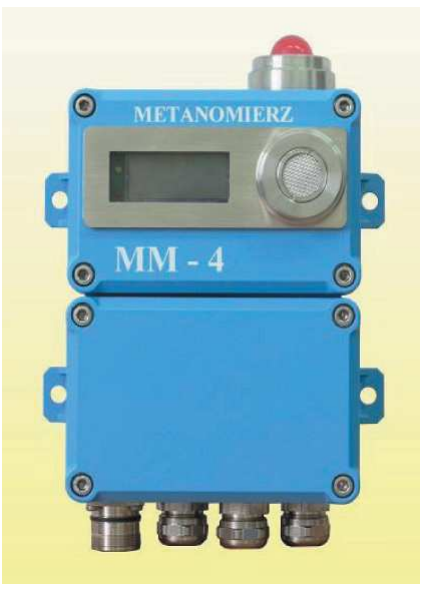

Fig. 1. MM-4 methane meter used for tests

\subsubsection{Stationary anemometer}

The AS-3 anemometer (Fig. 2) has been designed for the online measurement of airflow velocity in headings, tunnels, and corridors. It cooperates with underground switchboards. It was developed in two versions:

- AS-3n with a voltage output,

- AS-3c with a current output.
Temporarily, the ultrasound method has been used to measure velocity. The AS-3 anemometer can be used on an ad hoc basis as a mobile device. It is powered from an intrinsically safe battery supply.

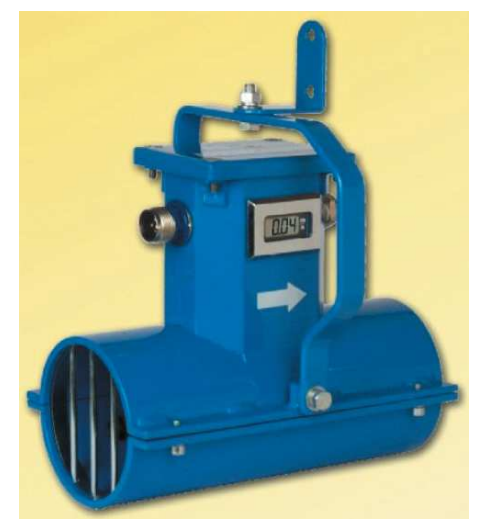

Fig. 2. AS-3 stationary anemometer

\subsubsection{THP-2 air physical parameters sensor}

The THP-2 stationary air physical parameters sensor (Fig. 3) conducts precise measurements of absolute pressure, temperature, and air humidity. The structure of the sensor is based on a small-size, high-precision SETRA 278 converter and a semiconductor temperature and humidity detector with a digital output. The software of the sensor enables the multi-point correction of converting characteristic and cooperation with a surface station in a methane- and fire-protection system.

The THP-2 physical air parameter sensor has very good qualitative and quantitative metrological parameters. Based on its readings, it is possible to determine aerodynamic potential values.

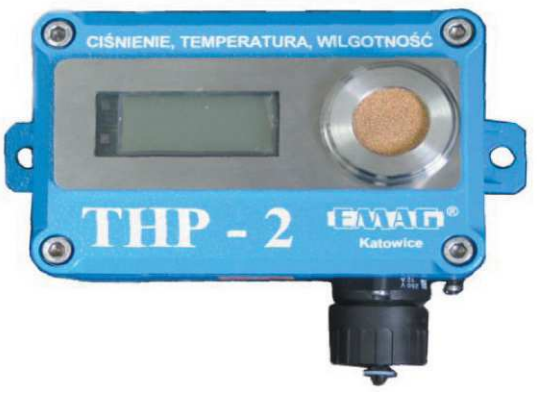

Fig. 3. THP-2 air physical parameter sensor

\subsubsection{Device for measuring methane drainage parameters}

The ZCO integrated methane drainage sensor (Fig. 4) has been designed to measure the volume of the drained methane [9]. The sensor is installed next to the methane 


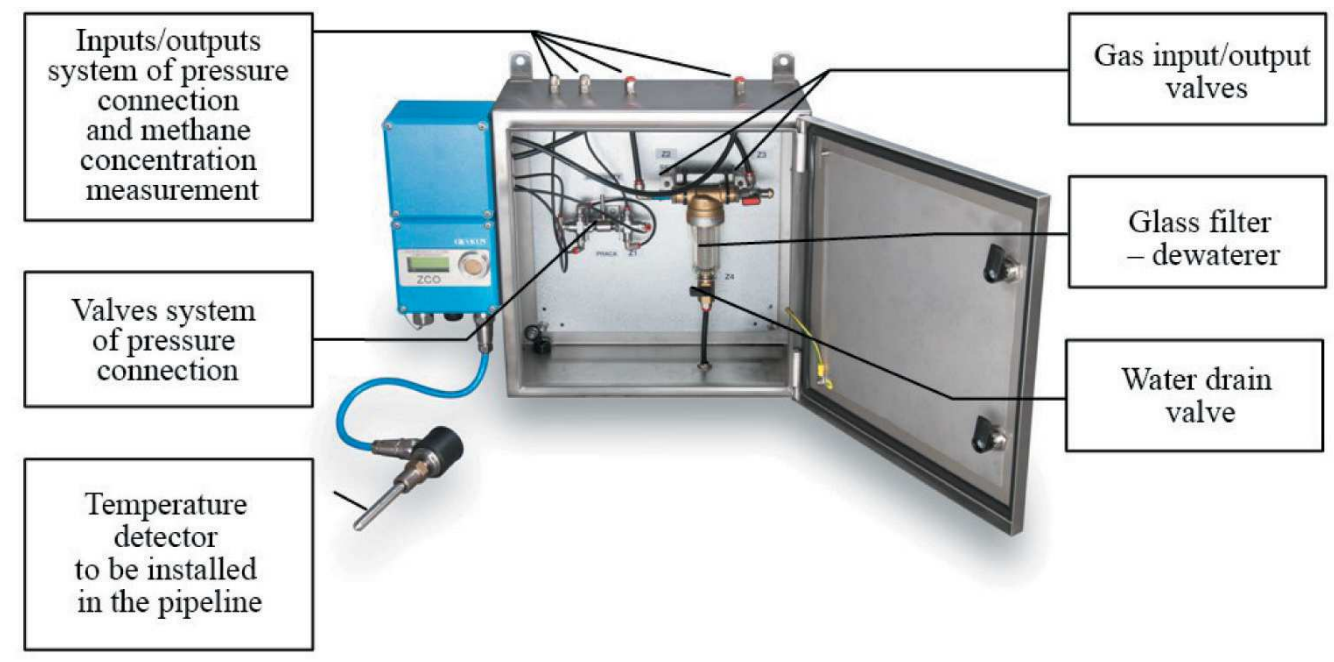

Fig. 4. ZCO Integrated methane drainage sensor

drainage pipeline, and the medium is provided to the measurement chamber by pneumatic drains. The sensor measures the physical parameters (pressure, differential pressure on the measuring orifice, temperature) and concentration of methane in the pipeline. The sensor is manufactured in two versions: one for the SMP-NT system and the other for an independent system with transmission in compliance with the RS-485 interface and a separate intrinsically safe power supply.

Based on online measurements, the sensor software determines the volume of pure methane in the pipeline using one of the two implemented methods: the simplified or iterative methods. The methane volumestream is calculated with respect to normal conditions $\left(P_{0}=1013.25 \mathrm{hPa}, T_{0}=0^{\circ} \mathrm{C}\right)$.

\subsection{Longwall used for tests}

In order to obtain data for the current analyses, there were some tests conducted in the excavations of the $\mathrm{N}-2$ longwall in the Pniowek hard coal mine [10]. This is a longwall with high methane content (where methane drainage is carried out as well). $\mathrm{N}-2$ is ventilated according to the Y-type ventilation system by means of a main fresh air stream coming along the $\mathrm{N}-2$ heading and the auxiliary (refreshing) stream provided to the longwall exit along the $\mathrm{N}-3$ heading.

The major objective of the tests carried out in the longwall area was to assess the possibility of applying:

- quantitative measurements for air and methane flow,

- a method of criteria-methane-bearing capacity to assess online the state of ventilation and methane hazard in the longwall area.
Article [14] presents the results of tests related to the calculations of the ventilation network during airflow changes, simulation of methane distribution from the place of raised methane concentration, and determination of methane-bearing capacity indicators in the longwall area.

In order to determine the values of parameters in each particular heading, the following devices were used: anemometers (heading $\mathrm{N}-2$, heading $\mathrm{N}-3$, rise gallery $\mathrm{N}-3$, drift $\mathrm{N}-12 \mathrm{a}$ ), methane meters (heading $\mathrm{N}-2$, heading $\mathrm{N}-3$, rise gallery $\mathrm{N}-3$ ), pressure and differential pressure sensors (inclined drift $\mathrm{N}-1$, heading $\mathrm{N}-3$, heading $\mathrm{N}-4$, heading $\mathrm{N}-4 \mathrm{a}$, rise gallery $\mathrm{N}-3$ ). Additionally, there was a sensor installed in the N-3 heading on the methane drainage pipeline for the online calculation of the values of a pure methane volumestream. The tests were conducted both with the use of extra sensors (methane, pressure) connected to the system and manual sensors. The distribution of sensors and measuring devices was performed in compliance with the regulations followed by the mine see Figure 5.

The test plan was as follows:

- installing measurement sensors at selected points of the longwall area,

- performing a passive experiment (observation and registration of parameters during normal operations of the longwall) and an active one (closing the T1 dam and opening it after several minutes),

- conducting measurements by manual and automatic velocity sensors working in the monitoring system. 


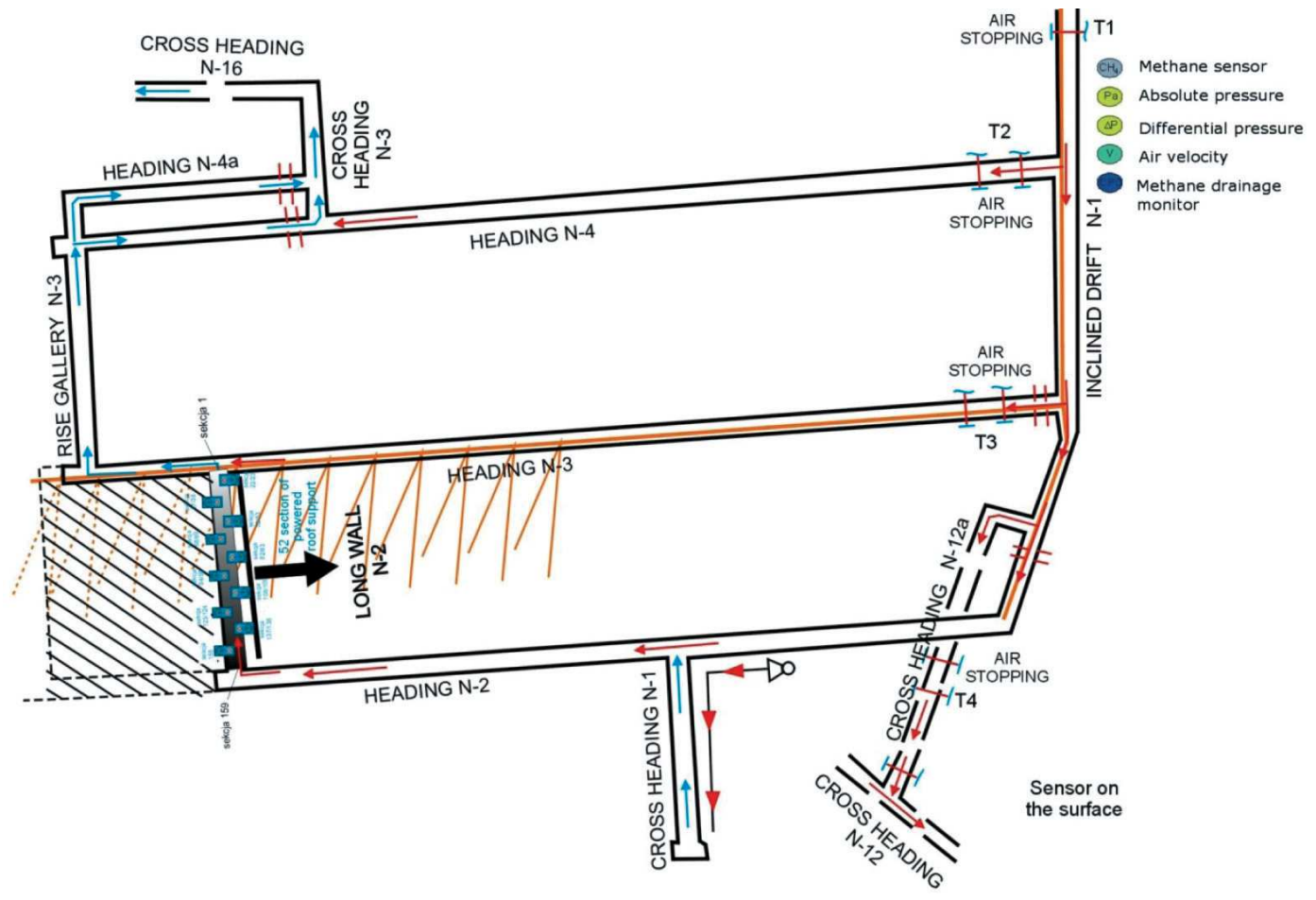

Fig. 5. Distribution of sensors in the N-2 longwall area

\section{TESTS RESULTS ANALYSIS}

\subsection{Ventilation-, absolute- and criteria-methane-bearing capacity}

GIG's manual [2] describes the rules of longwall management under the condition of methane hazard. Methane-bearing capacity is the quantity that describes the methane hazard in a longwall area. It is calculated on the basis of manually measured values of methane concentration and airflow velocity (air volume streams). The measurements are conducted periodically by the mine personnel. In order to characterize methane-bearing capacity in the longwall area, it is necessary to define the following terms:

- ventilation-methane-bearing capacity - the balance of pure methane output for the area, the difference between the methane measured in the used air stream and the methane contained in the fresh air stream,

- absolute-methane-bearing capacity - the total amount of methane emitted to the excavation (ventilation-methane-bearing capacity) and the methane drainage value,

- criteria-methane-bearing capacity - maximum absolute-methane-bearing capacity at which the permissible methane concentration values in the used air stream are not exceeded.
Criteria-methane-bearing capacity allows for a complete assessment of the methane hazard in a longwall area based on measurements of the volume of methane coming to the longwall with inflow air (main and refreshing), the volume of methane coming from the longwall area with ventilation air, and the volume of methane drained away by the methane drainage system. The value of criteria-methane-bearing capacity is determined for longwalls classified in methane hazard categories II, III, or IV. For projected longwalls, the values of methane-bearing capacity refer to the predicted absolute methane-bearing capacity, while for the currently exploited longwalls - to the absolute-methane-bearing capacity calculated on the basis of direct measurements.

The value of the criteria-methane-bearing capacity can be a condition to use methane drainage or other preventive measures that reduce the concentration of methane in the longwall area (e.g., air ducts) in the case of when the calculated value of criteria-methane-bearing capacity is smaller than the predicted or the real methane-bearing capacity occurring in the longwall area during exploitation.

The methane volume stream is calculated according to the following formula [2]:

$$
V=\frac{C_{m} \cdot V_{P W}}{100}\left[\frac{\mathrm{m}^{3}}{\mathrm{~min}}\right]
$$


The criteria value of the absolute-methane-bearing capacity $V_{K R}$ without a refreshing the air current is:

$$
V_{K R}=\frac{C_{m} \cdot V_{s} \cdot k}{100 \cdot n}-V_{D} \quad\left[\frac{\mathrm{m}^{3}}{\mathrm{~min}}\right]
$$

For longwalls with refreshing air currents, the value of the criteria-methane-bearing capacity is calculated from the following dependency:

$$
V_{K R}=\frac{C_{m} \cdot V_{s} \cdot k}{100 \cdot n}+\frac{V_{p}\left(\frac{C_{m}}{n}-C_{p}\right)}{100-\frac{C_{m}}{n}}-V_{D}\left[\frac{\mathrm{m}^{3}}{\min }\right]
$$

In the case of the methane drainage process conducted in the longwall area, the calculated value of methane-bearing capacity $V_{K R}$ should be substituted to the following dependency:

$$
V_{K R-O}=\frac{100 \cdot V_{K R}}{100-E}\left[\frac{\mathrm{m}^{3}}{\mathrm{~min}}\right]
$$

where the value of methane drainage $E$ is determined from the following formula:

$$
E=\frac{100 \cdot V_{O}}{V_{O}+V_{W}} \quad[\%]
$$

Symbols in the formulas (1)-(5) above stand for the following:

$C_{m}$ - admissible methane content [\%],

$C_{p}$ - methane concentration in refreshing air current [\%],

$V_{P}$ - volume stream of refreshing air current $\left[\mathrm{m}^{3} / \mathrm{min}\right]$,

$V_{S}$ - air volume stream in the longwall $\left[\mathrm{m}^{3} / \mathrm{min}\right]$,

$V_{D}$ - methane volume stream coming to the longwall $\left[\mathrm{m}^{3} / \mathrm{min}\right]$,

$V_{O}$ - volume of methane drained away by the drainage process $\left[\mathrm{m}^{3} / \mathrm{min}\right]$,

$V_{W}$ - volume of methane emitted to the excavations $\left[\mathrm{m}^{3} / \mathrm{min}\right]$,

$V_{P W}$ - air volume stream in the excavation $\left[\mathrm{m}^{3} / \mathrm{min}\right]$,

$k$ - irregularity coefficient of air distribution in the longwall,

$n$ - irregularity coefficient of methane emission.

\subsection{Calculating ventilation parameters}

Ventilation calculations were performed by the AERO2014 program [6,15] developed by the Silesian University of Technology and the IFK company. The application is responsible for the management and balance of air distribution in the mine ventilation network. This enables the modeling of changes, creation of simulations, and documentation of network parameters. It cooperates with spatial and canonical schemes of the mine in the AutoCAD environment.

The AERO2014 program calculates air volume streams based on the values of aero-dynamical resistance of side roads entered to a numerical model. The calculations are based on the Cross method [11], which makes use of the iterative method of successive approximations to the calculation of the set air distribution in networks made of multiple meshes.

The computing program is composed of two modules:

- Module of Standard Data Input (AERO2014),

- Graphical module based on an AutoCAD application.

The AERO2014 window is divided into three tabs:

- nodes - data about nodes within the mine structure,

- fans - fan operating parameters, where each parameter has its editable characteristics; in addition, polynomial coefficients of the device's characteristics are calculated,

- side roads - mathematical model of the mine ventilation network, describing the structure of ventilation connections between particular nodes.

The AERO2014 program enables operations in the supervision mode. Thus, it is possible to calculate the parameters of the ventilation network based on the readings of the measurement sensors. To achieve this, the following measurement devices are defined within the mine structure (along with their locations): pressure sensors [7] placed in nodes and air flow velocity sensors in side roads. Additionally, it is possible to define the gas sensors (e.g., methane meters). In order to perform the calculations, it is necessary to have a cross section of the side road at the place where the measurement is taken. A sample list of sensors entered to the AERO2014 program can be seen in Figure 6. 


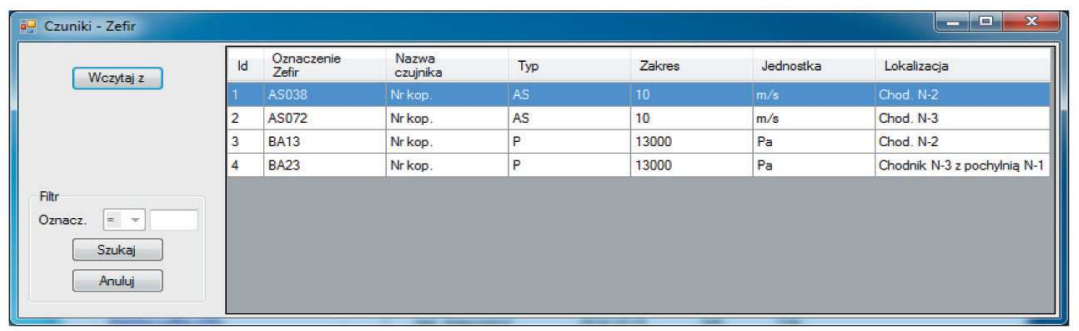

Fig. 6. Configuration window of sensors in the AERO2014 program

After all of the sensors have been defined, a function is invoked that controls the content in an XML file with the readings of previously defined devices. After having detected the file modification, AERO2014 calculates a new resistance value of the given side road as well as the values of air output in the whole mine. The new values are entered into the side road's structure. Thanks to the readings of pressure and air flow velocity values from the monitoring system, it is possible to dynamically calculate the resistance of the given side road and the distribution of air in the whole mine.

In addition, the program indicates emergency and alarm states in the gas sensors and, in the case of fire simulation, takes into account the devices' readings in the performed calculations.

\subsection{Calculating current air and methane output in the longwall area}

The methane-bearing capacity is calculated on the basis of averaged parameter values. However, serious methane hazard occurs when some parameters achieve extreme values (high methane concentration in the ventilation air, insufficient ventilation, and a low methane-drainage value at the same time). Calculating the current methane-bearing capacity, at the assumption that the irregularity coefficient of methane emission $n=1$ causes a situation where air volume and methane volume streams occur in the formulas.

The current criteria-methane-bearing capacity determines a safe methane volume stream, which develops
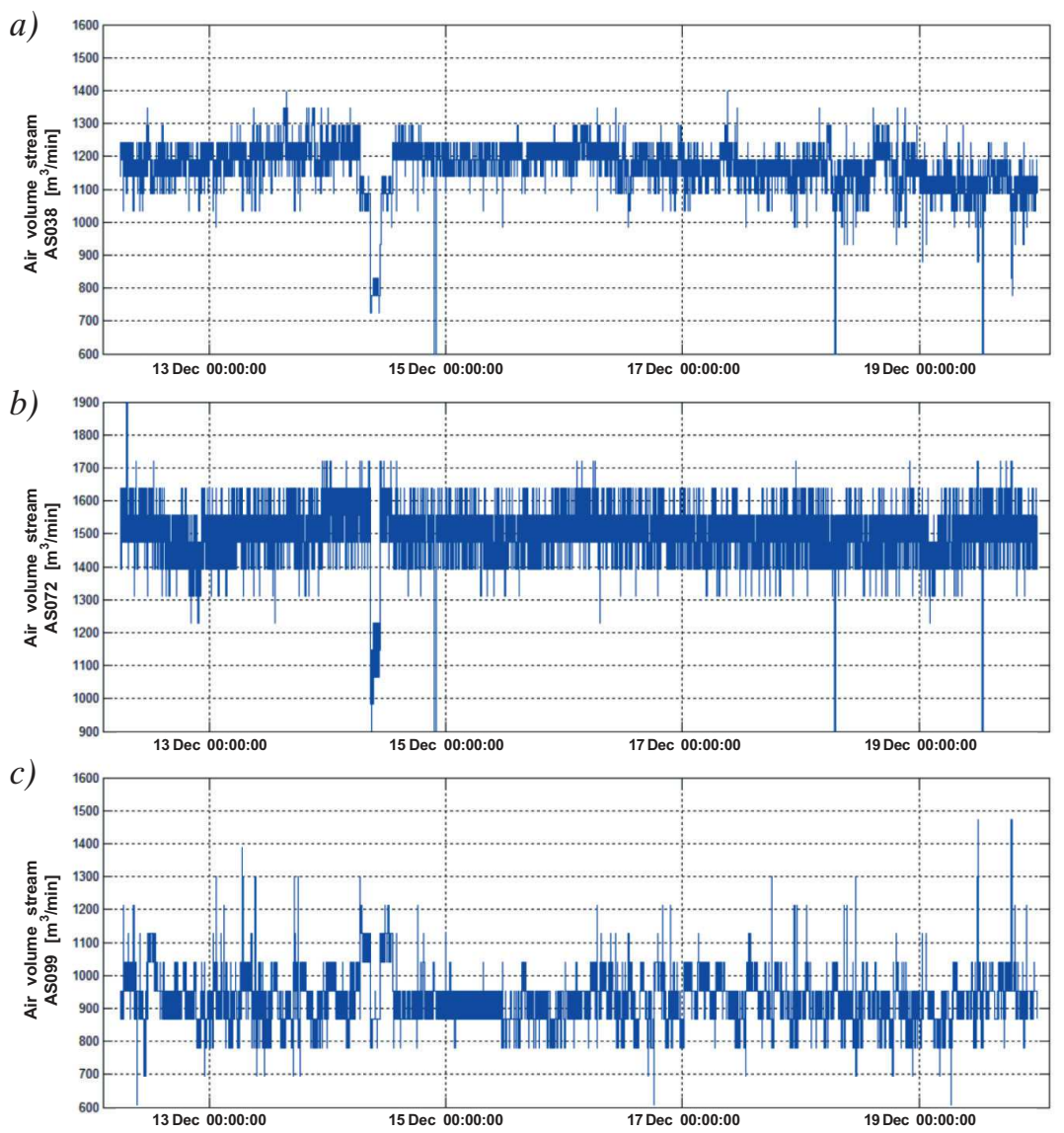

Fig. 7. Values of air output calculated on basis of air flows registered by anemometers: a) AS038; b) AS072; c) AS099 
during cutting operations at changing conditions of ventilation, methane drainage, and methane content in the air flowing into the longwall. On the other hand, the current absolute-methane-bearing capacity is a total value of the methane volume stream calculated on the basis of measurement data of return air from the longwall and the methane drainage data.

In order to calculate the methane volume stream in the ventilation air of the longwall area, air velocity sensors and methane meters in the $\mathrm{N}-2$ longwall were employed. In the N-2 headway, the AS038 anemometer and MM137 methane meter worked, and in the N-3 headway - the AS099 anemometer. Meanwhile, in the N-3 rise gallery, the measurements were registered by the AS072 anemometer and MM104 methane meter.

Based on the changing values of air flow velocity, air volume streams were calculated in the N-2 longwall area. The following cross sections of particular headings were used for the calculations:

- heading N-2 (anemometer AS038) - $8.63 \mathrm{~m}^{2}$,

- heading N-3 (anemometer AS099) $-14.45 \mathrm{~m}^{2}$,

- rise gallery N-3 (anemometer AS072 - $13.66 \mathrm{~m}^{2}$.

In addition, the value of coefficient $k=0.85$ (determined in [2]) was assumed for the calculations. Figure 7 fea- tures the determined values of air volume streams based on the registered values of air velocity in the $\mathrm{N}-2$ longwall area.

The obtained average values of the air volume stream were compared with the calculations made by the AERO interface. These values are presented in Table 1 .

Table 1

Average values of air output from measurements and AERO system as well as the conversion coefficient calculated on the basis of comparison

\begin{tabular}{|l|c|c|c|}
\hline Name & $\begin{array}{c}\text { Measured } \\
\text { value of vol- } \\
\text { ume stream } \\
{\left[\mathbf{m}^{\mathbf{3}} / \mathbf{m i n}\right]}\end{array}$ & $\begin{array}{c}\text { Value of volume } \\
\text { stream calculated } \\
\text { by AERO } \\
{\left[\mathbf{m}^{\mathbf{3}} / \mathbf{m i n}\right]}\end{array}$ & $\begin{array}{c}\text { Coeffi- } \\
\text { cient }\end{array}$ \\
\hline Heading N-2 & 1169.85 & 1314 & 1.123 \\
\hline Heading N-3 & 926.47 & 1566 & 1.690 \\
\hline Rise gallery N-3 & 1496.45 & 2880 & 1.925 \\
\hline
\end{tabular}

Based on this comparison, conversion coefficients for each measurement stand were estimated. This showed the difference between the calculations made by the program and the real measurements (Tab. 1). Figure 8 features the values of pure methane output in the ventilation air (calculated on the basis of air output values) as well as the conversion coefficients and methane concentration percentage in the $\mathrm{N}-2$ longwall area.
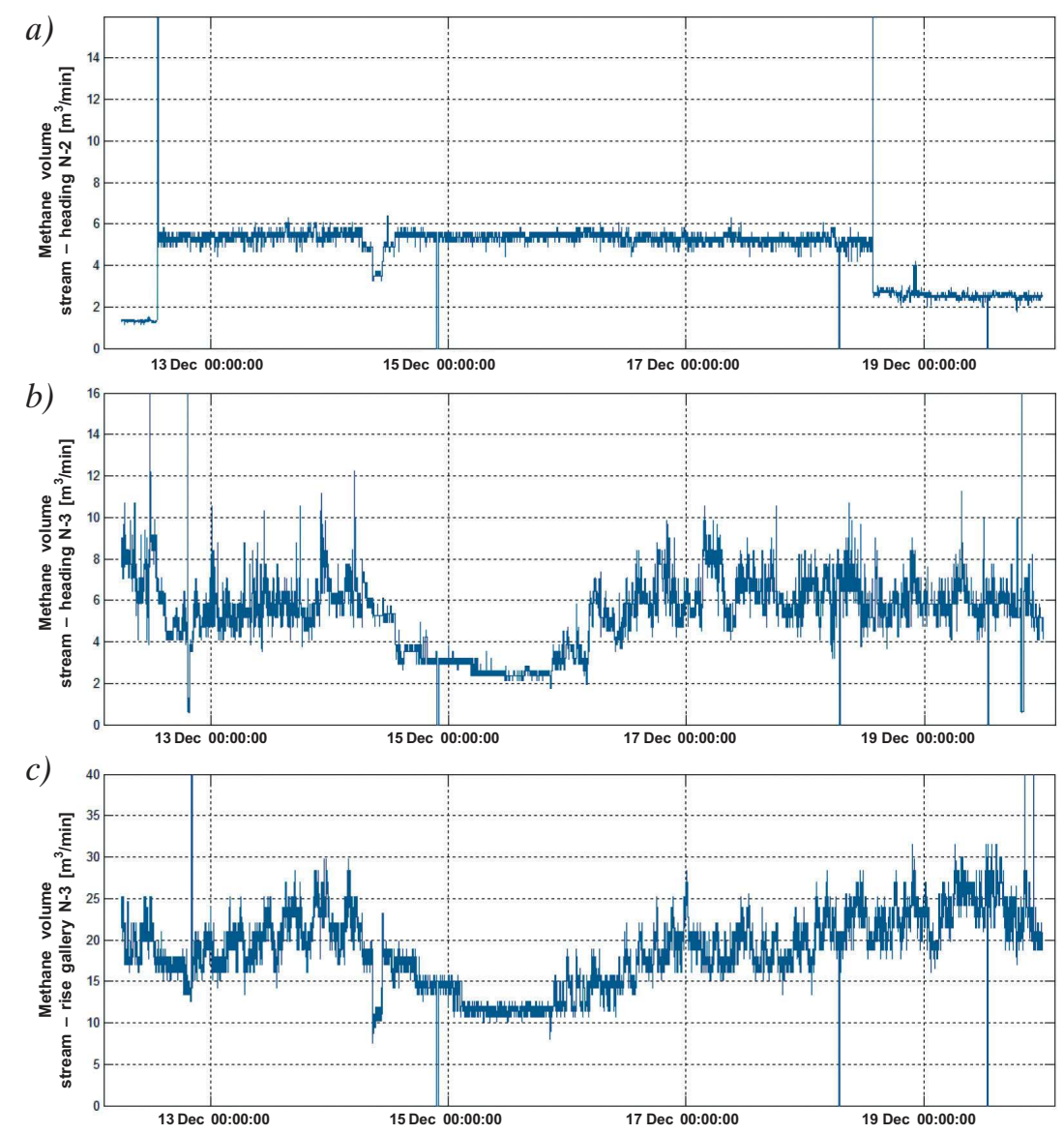

Fig. 8. Values of pure methane output in ventilation air in: a) heading $N-2 ; b$ ) heading $N-3 ; c$ ) rise gallery $N-3$ 


\subsection{Methane-hazard assessment based on the comparison of methane volume stream in the air and admissible ventilation-methane-bearing capacity}

The determined values of the pure methane volume stream allow us to calculate the ventilation-methane-bearing capacity in the N-2 longwall area. Figure 9a presents the values of the ventilation-methane-bearing capacity in a given period.

In order to calculate the value of the criteria-methane-bearing capacity, the following parameter values were utilized with the use of formula (3) determined in the design of the N-2 longwall [5]:

- admissible methane content $C_{m}$ is $2 \%$, while for the refreshing air stream $-1.5 \%$,
- irregularity coefficient $k$ of air distribution in the longwall is 0.85 ,

- average usable cross section of the longwall is $10.58 \mathrm{~m}^{2}$,

- irregularity coefficient n of methane distribution is 1.0 due to the online character of measurements and conversions based on the real output of air and methane,

- methane content $C_{p}$ in the refreshing current of the air volume stream $V_{s}$ in the longwall, refreshing air current volume stream $V_{p}$, and incoming methane volume stream $V_{D}$, converted on the basis of readings registered by measurement devices in the N-2 longwall area.

Due to the fact that methane drainage was applied in the N-2 longwall area, the criteria value of the methane-bearing capacity is calculated with respect to the methane drainage process based on formula (4).

a)

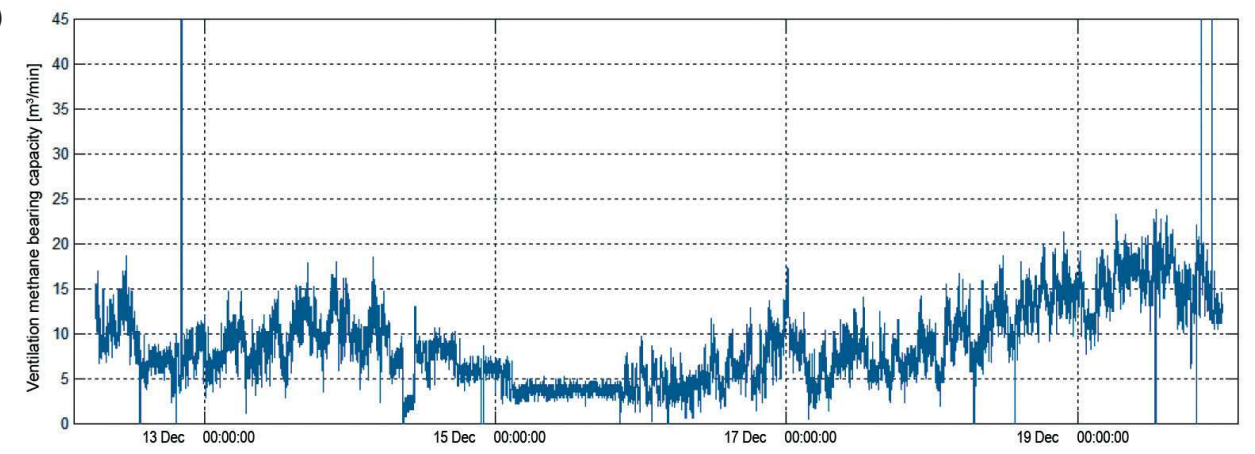

b)

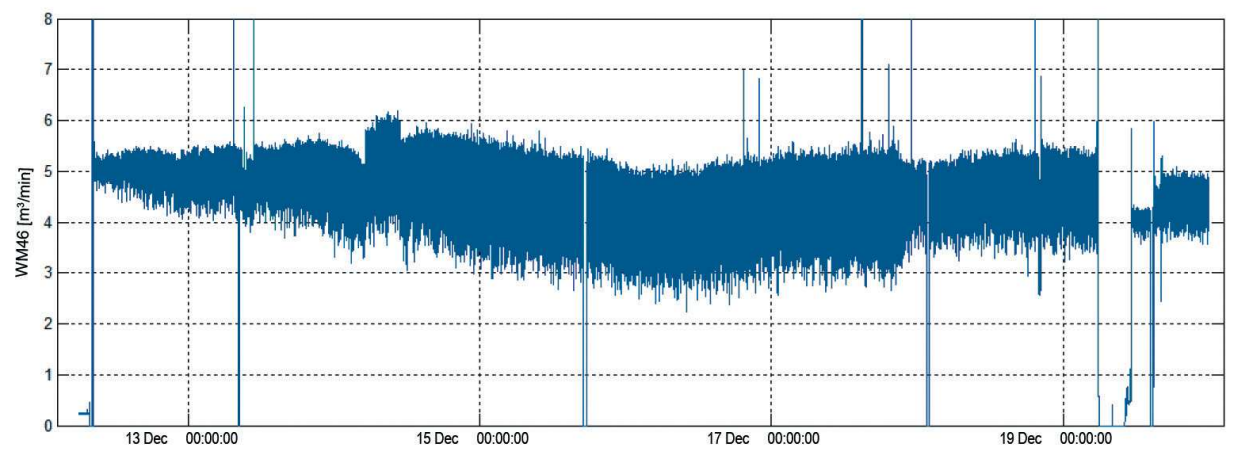

c)

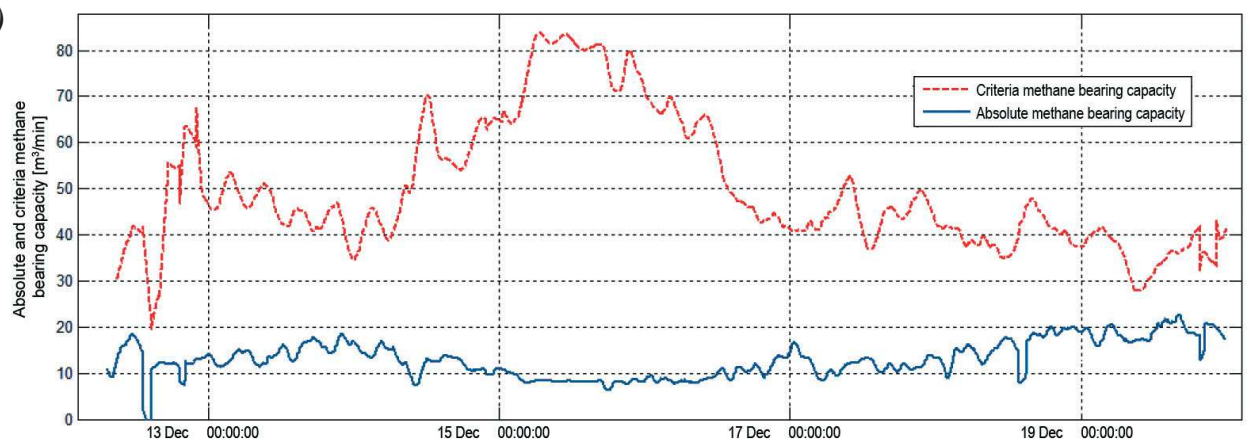

Fig. 9. Methane-bearing capacity in N-2 longwall area: a) ventilation methane bearing capacity; b) methane volume stream in methane drainage pipeline; c) absolute-methane-bearing capacity with marked level of criteria-methane-bearing capacity 
The measurement of methane output in the methane drainage pipeline is carried out by the ZCO sensor [8] working in the N-3 headway. The value of the output is calculated by iteratively measuring the parameters of the gas mixture according to standard [19] or by applying the following formula:

$$
V_{C H_{4}}=\% \mathrm{CH}_{4} \cdot 0,011 \cdot a \cdot E \cdot d^{2} \sqrt{\frac{P \cdot h}{s \cdot T}}\left[\frac{\mathrm{m}^{3}}{\mathrm{~min}}\right]
$$

where:

0.011 - numerical coefficient,

$a$ - flow coefficient calculated on the basis of the measurement reducer module,

$E$ - gas expansion coefficient,

$d$ - reducer diameter $[\mathrm{cm}]$,

$P$ - absolute pressure in the pipeline $[\mathrm{mm} \mathrm{Hg}]$,

$h$ - pressure drop on the measurement orifice [ $\mathrm{mm} \mathrm{H}_{2} \mathrm{O}$,

$T$ - absolute temperature of gas before the reducer $[\mathrm{K}]$,

$s-$ relative density of gas $\left[\mathrm{kg} / \mathrm{m}^{3}\right]$,

$\% \mathrm{CH}_{4}-$ methane concentration [\%].

The measured methane volume stream in the methane drainage pipeline is presented in Figure 9b. In order to calculate the values of the absolute-methane-bearing capacity, the following were totaled: the readings of the ventilation-methane-bearing capacity and of the volume stream of methane drained away by the methane drainage pipelines. Figure $9 \mathrm{c}$ features the registered absolute-methane-bearing capacity as well as the marked level of the criteria-methane-bearing capacity with respect to the methane drainage of the $\mathrm{N}-2$ longwall.

\section{CONCLUSIONS}

The following tests were necessary to assess the methane hazard in the excavation longwall areas:

- measurements of methane concentration and ventilation parameters (pressure and airflow velocity),

- measurements of methane drainage parameters in the collector pipeline coming from the longwall (measured methane concentration, pressure drop on the measurement reducer, absolute pressure, and gas temperature - these parameters allow us to calculate the current pure methane volume stream).
The results of the conducted tests allowed us to determine and calculate the online methane hazard based on the online analysis of ventilation and criteria-methane-bearing capacity as well as the methane drainage efficiency, which makes use of the measurements taken from airflow velocity sensors and methane sensors. In addition, the tests enable us to calculate the methane volume stream from the methane drainage pipeline.

The measurements of airflow velocity for calculating volume streams in the longwall-gallery side roads of the ventilation network were carried out with the use of two methods:

- manual method in compliance with the mining measurement technology (continuous traverse method [4]),

- automatic method in the monitoring system (spot metering with respect to the air velocity distribution coefficient in the cross section of the excavation).

The values of airflow determined by means of different methods were significantly different in some cases. It will be necessary to work out the characteristics for different values of air velocity for typical spots of the ventilation network. Here, it will be very helpful to consult the results of projects conducted by research organizations [16-18].

The tests results are the base s to develop:

- the structure and functions of a monitoring system that would also perform selected ventilation and gas analyses,

- software performing the functions of the analyses.

\section{References}

[1] Pawiński J., Roszkowski J., Strzemiński J.: Przewietrzanie kopalń, Śląskie Wydawnictwa Techniczne, Katowice 1995.

[2] Krause E., Łukowicz K.: Zasady prowadzenia ścian w warunkach zagrożenia metanowego, Instrukcja $\mathrm{nr} 17$ GIG, Katowice - Mikołów 2004.

[3] Miśkiewicz K., Wojaczek A., Wojtas P.: Systemy dyspozytorskie kopalń podziemnych $i$ ich integracja. Wybrane problemy, Wydawnictwo Politechniki Śląskiej, Gliwice 2011.

[4] Roszczynialski W., Trutwin W., Wacławik J.: Kopalniane pomiary wentylacyjne, Wydawnictwo Śląsk, Katowice 1999.

[5] Documentation of longwall N-2 in seam 404/2 in Pniówek hard coal mine, Pawłowice 2013.

[6] AERO2014: Information materials by IFK (Informatyczna Firma Konsultingowa).

[7] Broja A., Felka D., Mróz J., Skierś P.: Badania czujników ciśnienia powietrza dla celu ciagłego monitorowania, EMTECH, Szczyrk 2014. 
[8] Broja A., Małachowski M., Felka D.: Monitorowanie parametrów odmetanowania $w$ kontekście ich wplywu na wartości metanowości $w$ rejonie ściany, Materials of EMTECH Conference "Zasilanie, telemetria i automatyka w przemyśle wydobywczym. Innowacyjność i bezpieczeństwo”. Zakopane 2015.

[9] Felka D., Broja A.: Pomiary parametrów do wyliczenia strumienia objętości metanu $w$ rurociagach sieci odmetanowania, in: Mechanizacja, automatyzacja $i$ robotyzacja w górnictwie: monografia, red. nauk. K. Krauze, Centrum Badań i Dozoru Górnictwa Podziemnego, Katedra Maszyn Górniczych, Przeróbczych i Transportowych AGH, Kraków 2014, pp. 72-82.

[10] Documentation of European project AVENTO: "Zaawansowane narzędzia do kontroli wentylacji i emisji metanu", Instytut Technik Innowacyjnych EMAG, Katowice 20142015.

[11] Cross H.: Analysis of flow in networks of conduits or conductors, "Engineering Experiment Station", Bulletin No. 286, University of Illinois 1936.

[12] Catalogue cards and websites of the manufacturers of measurement devices and sensors: Instytut EMAG (www.ibemag.pl), SEVITEL sp. z o.o. (www.sevitel.pl), EMAG-SERWIS sp. $\mathrm{z}$ o.o. (www.emagserwis.pl), MICON sp. z o.o. (www.micon.pl), CARBOAUTOMATYKA S.A. (www.carbo.com.pl), HASO S.C. (haso.pl).

[13] Cierpisz S., Miśkiewicz K., Wojaczek A.: Systemy gazometryczne $w$ górnictwie, Wydawnictwo Politechniki Śląskiej, Gliwice 2007.

[14] Krzystanek Z., Mróz J., Trenczek S.: Zintegrowany system monitorowania $i$ analizy zagrożenia metanowego $w$ rejonie ściany wydobywczej, "Mining - Informatics, Automation and Electrical Engineering" 2016, 1: 64-76.
[15] Knapczyk J., Musioł D.: Wykorzystanie systemu Aero do podniesienia bezpieczeństwa $w$ wyrobiskach górniczych poprzez monitoring wentylacyjny, in: Narzędzia informatyczne wspomagajace prognozowanie $i$ monitoring oraz szkolenia $w$ zakresie zagrożen występujących $w$ kopalniach - teoria i praktyka, red. D. Musioł, P. Pierzyna, Instytut Eksploatacji Złóż Politechniki Śląskiej, Gliwice 2015.

[16] Dziurzyński W., Wasilewski S.: Ocena zagrożenia metanowego $w$ rejonie ściany na podstawie czujników gazometrii oraz symulacji komputerowej przepływu mieszaniny powietrza i metanu, "Przegląd Górniczy" 2012, 12: 28-34.

[17] Wasilewski S.: Kontrola prędkości powietrza $w$ wyrobiskach kopalni $w$ systemach nadzoru dyspozytorskiego, "Przegląd Górniczy” 2013, 7: 1-13.

[18] Wasilewski S.: Monitorowanie zakłóceń parametrów powietrza $w$ systemach dyspozytorskiego nadzoru powstatych $w$ wyniku krótkiego spięcia, "Przegląd Górniczy" 2015, 11: 33-43.

[19] PN-EN ISO 5167-1:2005: Pomiary strumienia plynu za pomoca zwężek pomiarowych wbudowanych $w$ catkowicie wypetnione rurociagi o przekroju kołowym. Część 1: Zasady $i$ wymagania ogólne.

$$
\begin{array}{r}
\text { JERZY MRÓZ, Ph.D., Eng. } \\
\text { DARIUSZ FELKA, M.Sc., Eng. } \\
\text { ADAM BROJA, M.Sc., Eng. }
\end{array}
$$

MARCIN MAEACHOWSKI, Ph.D., Eng.

Institute of Innovative Technologies EMAG ul. Leopolda 31, 40-189 Katowice, Poland

\{J.Mroz, D.Felka, A.Broja, M.Malachowski\}@ibemag.pl 